\title{
KAJIAN BERTAHAN HIDUP PEMULUNG DI TEMPAT PEMBUANGAN AKHIR SAMPAH KELURAHAN SUMOMPO KECAMATAN TUMINTING, MANADO
}

\author{
Angelyk Y. F. Kawalo \\ Charles R. Ngangi \\ Agnes E. Loho
}

\begin{abstract}
Objective of this research was to assess the survival mechanism scavenger in landfills Sumompo, Tuminting Village District of Manado. Location of research is determined by purposive sampling while sample are scavengers who had worked more than 10 years as many as 15 people. Secondary data were obtained from the office of the Department of Sanitation, Parks and Office of Manado City and the Sumompo village Office. The analytical method used is descriptive statistics. The results showed that survival mechanism scavengers in landfill sites Sumompo based on food needs, performed with diet twice a day morning and afternoon with a fried or steamed fish and sometimes with vegetables. Based on the needs of clothing, they bought clothes once a year or of giving people and others acquired from landfills. Almost of scavengers home are made from plywood with a size of $20 \mathrm{~m}^{2}$ to $42 \mathrm{~m}^{2}$. Income ranges from $\mathrm{Rp}$ 1,000,000 to $R p 1886$ 666. Equipment purchased in most homes and others obtained from trash.
\end{abstract}

Key words: survival of life, scavengers, food needs, clothing needs, and homeneeds

\begin{abstract}
ABSTRAK
Penelitian ini bertujuan untuk mengkaji mekanisme bertahan hidup pemulung di tempat pembuangan akhir (TPA) sampah di Kelurahan Sumompo Kecamatan Tuminting Manado. Tempat penelitian ditentukan secara purposive sampling sedangkan contoh adalah pemulung yang sudah bekerja lebih dari 10 tahun sebanyak 15 orang. Data sekunder diperoleh dari Kantor Dinas Kebersihan, Pertamanan Kota Manado dan Kantor kelurahan Sumompo. Metode analisis yang digunakan adalah statistika deskriptif. Hasil penelitian menunjukkan bahwa mekanisme bertahan hidup pemulung di lokasi TPA Sumompo berdasarkan kebutuhan pangan, dilakukan dengan pola makan dua kali sehari pagi dan sore dengan lauk ikan goreng atau kukus dan terkadang dengan sayur. Berdasarkan kebutuhan sandang, pemulung di TPA Sumompo rata-rata membeli pakaian satu kali dalam setahun baik dibeli sendiri ataupun dari pemberian orang dan yang lain diperoleh dari tempat pembuangan akhir. Rumah para pemulung rata- terbuat dari tripleks dengan ukuran dari $20 \mathrm{~m}^{2}$ sampai $42 \mathrm{~m}^{2}$. Pendapatan berkisar antara $\mathrm{Rp} 1.000 .000$ hingga Rp 1886 666. Peralatan dalam rumah sebagian dibeli dan lainnya diperoleh dari tempat sampah
\end{abstract}

Kata kunci: bertahan hidup, pemulung, kebutuhan sandang, kebutuhan pangan,kebutuhan papan 


\section{PENDAHULUAN}

\section{Latar Belakang}

Salah satu bentuk kegiatan sektor informal yang cukup menarik saat ini yaitu pe mulung. Keterbatasan lahan dan kemiskinan di daerah pedesaan, serta tidak tersedianya lapangan pekerjaan yang sesuai dengan pengetahuan dan keterampilan di daerah perkotaan menjadi penyebab mereka bekerja sebagai pemulung. Bekerja sebagai pemulung di daerah perkotaan juga muncul akibat adanya nilai ekonomi dari sampah dan banyaknya jumlah sampah yang dihasilkan masyarakat. Pemulung beranggapan bahwa sampah adalah ladang yang dapat menghidupi keluarga mereka (Susanti dkk, 2012).

TPA Sampah Sumompo merupakan salah satu TPA sampah tertua di kota Manado yang terletak di Kecamatan Tuminting. TPA ini telah menjadi sumber penghidupan para pemulung di Kota Manado. Data tentang jumlah penduduk di sekitar TPA tahun 2015 dari kantor kelurahan Sumompo berjumlah 318 KK yang berada di lingkungan III, dimana $95 \%$ bekerja sebagai pemulung, buruh sampah, tukang sapu dan sopir mobik/oto sampah, dengan jumlah pemulung berjumlah 150 orang. Bagaimana kehidupan para pemulung di lokasi ini menarik untuk diteliti. Oleh karena itu penulis tertarik untuk meneliti tentang kehidupan pemulung di TPA Sampah di Kelurahan Sumompo Kecamatan Tuminting Kota Manado.

Teori yang sangat terkenal tentang kebutuhan dasar manusia adalah teori dari Abraham H. Maslow tentang Hierarchy of Needs (Hirarki Kebutuhan). Menurut Maslow dalam Notoatmodjo (2003), bahwa manusia termotivasi untuk memenuhi kebutuhankebutuhan hidupnya. Kebutuhan-kebutuhan tersebut memiliki tingkatan atau hirarki, mulai dari yang paling rendah (bersifat dasar/fisiologis) sampai yang paling tinggi (aktualisasi diri). Teori hirarki kebutuhan dari Maslow menyatakan bahwa manusia memiliki 5 macam kebutuhan yaitu physiological needs (kebutuhan fisiologis), safety and security needs (kebutuhan akan rasa aman), love and belonging needs (kebutuhan akan rasa kasih sayang dan rasa memiliki), esteem needs (kebutuhan akan harga diri), dan self-actualization (kebutuhan akan aktualisasi diri).

Berdasarkan teori hirarki kebutuhan Maslow, maka kebutuhan-kebutuhan di tingkat rendah harus terpenuhi atau paling tidak cukup terpenuhi terlebih dahulu sebelum kebutuhan-kebutuhan di tingkat lebih tinggi. Kebutuhan-kebutuhan di tingkat rendah tersebut di antaranya adalah kebutuhan akan sandang, pangan, dan papan.

\section{Perumusan Masalah}

Berdasarkan latar belakang yang telah dikemukakan, maka yang menjadi masalah dalam penelitian ini yaitu: Bagaimana pemulung bertahan hidup di Tempat Pembungan Akhir (TPA) Sampah Kelurahan Sumompo Kecamatan Tuminting Kota Manado?

\section{Tujuan dan Manfaat Penelitian}

Penelitian ini bertujuan untuk mendeskripsikan mekanisme bertahan hidup pemulung di tempat pembuangan akhir (TPA) sampah, di Kelurahan Sumompo Kecamatan Tuminting Kota Manado

Teori mekanisme survival yang sangat populer dikemukan oleh James C. Scott dalam bukunya yang berjudul Moral Ekonomi Petani; Pergolakan dan Subsistensi di Asia Tenggara (Scott, 1989). Teori tersebut memandang bahwa ada tiga cara yang dilakukan masyarakat miskin untuk bertahan hidup, yaitu:

1. Mengurangi pengeluaran untuk pangan dengan jalan makan hanya sekali sehari dan beralih ke makanan yang mutunya lebih rendah.

2. Menggunakan alternatif subsistensi yaitu swadaya yang mencakup kegiatan seperti berjualan kecil-kecilan, bekerja sebagai 
tukang, sebagai buruh lepas, atau melakukan migrasi untuk mencari pekerjaan. Cara ini dapat melibatkan seluruh sumber daya yang ada di dalam rumah tangga miskin, terutama istri sebagai pencari nafkah tambahan bagi suami.

3. Meminta bantuan dari jaringan sosial seperti sanak saudara, kawan-kawan sedesa, atau memanfaatkan hubungan dengan pelindungnya (patron), dimana ikatan patron dan kliennya (buruh) merupakan bentuk asuransi dikalangan petani. Patron menurut definisinya adalah orang yang berada dalam posisi untuk membantu klien-kliennya. Patron dalam kehidupan petani adalah pemilik modal yang dapat membantu kesulitan keuangan yang dihadapi petani.

Menurut Clark dalam Sumarno (2015), strategi-strategi yang di lakukan untuk mengatasi permasalahan kebutuhan hidup, yaitu:

1. Strategi pertama berupa pertukaran timbalbalik berupa uang, barang, dan jasa untuk kebutuhan sehari-hari dan kebutuhan yang mendadak, seperti kerebat dekat, tetangga, kerabat luas, maupun rekan kerja (Informal Sosial Support Networks).

2. Strategi kedua yaitu mengubah komposisi rumah tangga dengan menitipkan anak kepada neneknya di desa, sehingga dengan cara ini dapat mengurangi biaya hidup di perkotaan (Flexibel household composition).

3. Strategi ketiga yaitu dengan menganekaragamkan sumber usaha, misalnya bekerja menjadi pembantu rumah tangga, pelayan toko, menjual makanan, dsb. Strategi ketiga di lakukan karena keterbatasan waktu, keterampilan, modal, serta informasi yang di peroleh.

Strategi lain yang dilakukan untuk mensiasati kekurangan dalam memenuhi kebutuhan ialah memanfaatkan kredit informal, mengikuti arisan, menjual barangbarang simpanan, menggadaikan barang, lembur di tempat kerja, atau meminta kiriman dari orang tua, serta ada juga yang mengurangi jumlah makan dalam tiap harinya, dan menempati tempat sempit untuk di gunakan beberapa orang sehingga dapat memperkecil biaya yang akan di tanggung (unauthorized lanuse/squatting).

\section{METODOLOGI PENELITIAN}

\section{Waktu dan Tempat Penelitian}

Penelitian ini dilaksanakan selama tiga bulan dari bulan November 2015 sampai bulan Januari 2016 mulai dari persiapan, pengambilan data sampai penyusunan laporan. Tempat penelitian di Tempat Pembungan Akhir (TPA) Sampah Kelurahan Sumompo Kecamatan Tuminting Kota Manado.

\section{Metode Pengumpulan Data}

Lokasi penelitian ditentukan secara sengaja berdasarkan tempat pembuangan sampah akhir terbesaryaitu Kelurahan Sumompo Kecamatan Tuminting Kota Manado. Data yang digunakan adalah data prime dan data sekunder

Data primer diperoleh melalui wawancara dengan para pemulung di lokasi TPA. Wawancara dilakukan dengan menggunakan daftar pertanyaan yang terdiri dari pertanyaan terbuka dan pertanyaan tertutup. Data sekunder diperoleh melalui Kantor Dinas Kebersihan dan Pertamanan Kota Manado serta Kantor Kelurahan Sumompo Kecamatan Tuminting.

Jumlah sampel diambil secara acak sebanyak $10 \%$ untuk diwawancarai yakni 15 responden berdasarkan yang paling lama tinggal/berdiam dan bekerja sebagai pemulung di lokasi TPA Sumompo.

\section{Konsep Pengukuran Variabel}

1. Bertahan hidup pemulung yang merupakan cara bertahan hidup untuk memenuhi 
kebutuhan keluarga:

a. Sandang, yaitu berapa kali mereka membeli pakaian dalam setahun; Jika dibeli, dimana dan harga serta jumlahnya; Jika mendapat sumbangan, disumbangkan orang oleh siapa.

b. Pangan, mereka makan sehari-hari, berapa kali dalam satu hari, dan apa saja yang dimakan sebagai lauk-pauk.

c. Papan, mereka menempati rumah tinggal sekarang, sewa, beli atau bangun sendiri, berapa ukuran dan berapa lama tinggal.

d. Pendidikan anak: menyekolahkan anak, ada dana BOS, beasiswa, atau bayar sendiri dan kebutuhan sekolah, bagaimana mereka mengusahakan itu.

e. Kesehatan yaitu bila sakit berobat ke Pus kesmas, Rumah Sakit, Klinik, dokter, atau beli di warung atau apotik. Biayanya menggunakan BPJS, atau Dana sehat, dan sebagainya. Jika tidak bagaimana penanganannya jika sakit.

f. Kebutuhan lainnya berupa kegiatan sosial ikut arisan, menabung, dan atau rukun. Koperasi, dan sebagainya.

2. Pendapatan pemulung adalah pendapatan yang diperoleh dari hasil memulung dan pendapatan dari sumber-sumber lain dari anggota keluarga, diukur dalam satuan rupiah per bulan.

3. Pengeluaran rumah tangga adalah pengeluaran untuk makan (Rp/hari), pakaian (Rp), tempat tinggal, pendidikan anak, pengobatan/kesehatan dan kebutuhan lainnya, diukur dalam rupiah per bulan.

\section{HASIL \& PEMBAHASAN}

\section{Gambaran Umum TPA Sumompo}

TPA Sampah Sumompo merupakan TPA sampah tertua di kota Manado yang terletak di Kecamatan Tuminting. TPA ini telah menjadi sumber penghidupan para pemulung di lokasi ini yang dibangun sejak tahun 1972. Dengan demikian keberadaan TPA ini sudah 43 tahun lamanya.

Luas TPA sampah Sumompo saat ini 10 hektar, sebelumnya berjumlah 6 hektar namun dengan kondisi bertambahnya produksi sampah dari tahun ke tahun maka diadakan penambahan luas sejumlah 4 hektar dengan pembebasan lahan yang sudah selesai dilaksanakan. Dengan adanya pembebasan lahan ini direncanakan akan dibuat system landfill. Pengembangan sistem sanitari landfill ini merupakan metode pemusnahan sampah dengan membuang dan menumpuk sampah ke suatu lokasi yang cekung (lubang), memadatkan sampah tersebut kemudian menutupnya dengan tanah. Metode ini dapat menghilangkan polusi udara dan lingkungan.

Tabel 1. Produksi Sampah di Kota Manado

\begin{tabular}{lcc}
\hline No & Tahun & Produksi Sampah \\
\hline 1. & 2011 & $828.812 \mathrm{~m}^{3}$ \\
2. & 2012 & $840.960 \mathrm{~m}^{3}$ \\
3. & 2013 & $940.703 \mathrm{~m}^{3}$ \\
4 & 2014 & $980.865 \mathrm{~m}^{3}$ \\
\hline
\end{tabular}

Sumber: Dinas Kebersihan \& Pertamanan Kota Manado, Tahun 2015

\section{Gambaran Responden}

Pendidikan pemulung tergolong rendah karena hanya satu responden yang berlatar belakang pendidikan SMA, sedangkan pemulung yang lain hanya sampai jenjang SD. Lama mereka melakukan pekerjaan ini berkisar antara $9-29$ tahun. Usia mereka saat mulai menjalankan profesi ini berkisar antara $17-44$ tahun. Pemulung yang sudah berusia 44 tahun baru memulung selama sembilan tahun.

Keaktifan responden umumnya di bidang kerohanian, dan arisan buruh sampah. Jika ada kebutuhan mendesak yang harus ditanggulangi, maka responden akan meminjam ke sesama pemulung, koperasi atau ke pemilik ternak. 
Tabel 2. Distribusi Responden menurut Kelompok Umur

\begin{tabular}{ccc}
\hline $\begin{array}{l}\text { Kelompok } \\
\text { Umur }\end{array}$ & Jumlah & Persen \\
\hline 41 tahun & 4 & 26,67 \\
$41-49$ & 5 & 33,33 \\
$>49$ & 6 & 40,00 \\
\hline Jumlah & 15 & 100,00 \\
\hline
\end{tabular}

Sumber : Data primer, 2016 (diolah)

Umur responden Umur responden berkisar antara 37-53 tahun yang dapat dilihat pada Tabel 2. Tabel 2 menunjukkan bahwa usia pemulung umumnya sudah berumur 50 tahun.

\section{Penghasilan Pemulung}

Pada Tabel 3 memberikan gambaran mengenai penghasilan pemulung yang sudah dikonversi ke rupiah per bulan. Penghasilan pemulung dimaksud ialah pendapatan dari hasil rata-rata per hari yang diterima dalam bentuk penjualan hasil memungut sampah berupa makanan untuk ternak babi. Penghasilan ini ada pemulung yang mendapatkan Rp 50.000 sampai Rp 60.000 per hari dan ada yang Rp 90.000 sampai Rp 100.000/hari.

Tabel 3. Rata-rata Penghasilan Pemulung

\begin{tabular}{ccc}
\hline Penghasilan & Jumlah & Persen \\
(Rp/bulan) & Pemulung & \\
&
\end{tabular}

\begin{tabular}{rcc}
\hline$<1.250 .000$ & 1 & 6,67 \\
$1.250 .000 \mathrm{~s} / \mathrm{d}$ & 9 & 60,00 \\
3.000 .000 & & \\
$>3.000 .000$ & & \\
& 5 & 33,33 \\
\hline Jumlah & 15 & 100,00 \\
\hline
\end{tabular}

Sumber: Data primer, 2016 (diolah)

Penghasilan pemulung saat ini berkisar antara Rp 1.000.000 dan Rp 3.600.000 yang secara lengkap dapat dilihat pada Tabel 3. Sebelumnya lebih rendah dibandingkan dengan yang sekarang

Sebelum adanya system landfill responden hanya memulung sampah-sampah plastik yang bisa di jual kembali namun harganya relatif murah. Saat ini dengan berkembangnya rumah makan di Kota Manado menyebabkan banyaknya sisa-sisa makanan yang dapat dijual sebagai makanan babi yang bernilai Rp 3000/kg. Hal ini memberikan dampak pada peningkatan pendaptan responden.

\section{Kajian Bertahan Hidup Pemulung}

Mekanisme bertahan hidup pemulung di lokasi TPA Sampah Sumompo yang dikaji berdasarkan pangan, sandang dan papan .

\section{Kebutuhan Pangan}

Pemenuhan kebutuhan pangan responden umumnya didasarkan pada karbohidrat dan protein dengan pola makan yang dituangkan pada Tabel 4 di bawah ini

Tabel 4. Pola Makan Keluarga Pemulung di TPA Sumompo

\begin{tabular}{cccc}
\hline No & Pola Makan & Jumlah & Persen \\
\hline 1. & Pagi- Siang - Malam & 5 & 33,33 \\
2. & Pagi - Sore & 10 & 66,67 \\
3. & Siang - Malam & 0 & 0 \\
\hline & Jumlah & 15 & 100,00
\end{tabular}

Sumber: Data primer, 2016 (diolah)

Berdasarkan pola makan responden, maka responden dalam sehari umumnya makan dua kali pada waktu pagi dan sore hari dengan lauk ikan goreng atau kukus, kadang-kadang ditambah sayuran. . Para pemulung ini hanya makan pagi dan sore dengan alasan bahwa untuk malam hari mereka hanya minum kopi dan camilan bahkan merokok karena berikut lagi mereka akan memulung disebabkan karena ada mobil sampah yang masuk pada malam hari. Dengan demikian mereka bisa 
berhemat untuk pengeluaran makanan setiap hari.

\section{Kebutuhan Sandang}

Responden memenuhi Kebutuhan akan sandang dengan membeli pakaian ada yang hanya satu kali dalam setahun, dua kali dalam satu tahun bahkan ada yang tidak pernah membeli pakaian melainkan hanya memperoleh dari pemberian orang ataupun diperoleh dari tempat sampah. Tabel 8 menunjukkan pembelian pakaian bagi pemulung dan keluarganya dalam satu tahun.

Tabel 5. Pembelian Pakaian Pemulung dan Keluarganya dalam Setahun

\begin{tabular}{llcc}
\hline No & $\begin{array}{l}\text { Pembelian } \\
\text { Pakaian } \\
\text { Setahun }\end{array}$ & $\begin{array}{c}\text { Jumlah } \\
\text { Responden }\end{array}$ & Persen \\
\hline 1. & Tidak pernah & 6 & \\
2. & Satu kali & 6 & 40,00 \\
3. & Dua kali & 3 & 20,00 \\
\hline & Jumlah & 15 & 100,00 \\
\hline
\end{tabular}

Sumber: Data primer, 2016 (diolah)

Bagi pemulung dan keluarganya yang dua kali dalam setahun membeli pakaian ada sebanyak 3 responden yang menyatakan bahwa membeli pakaian untuk anak-anak saja sedangkan orangtua tidak membeli pakaian dalam setahun belakangan ini. Pembelian pakaian ini dilakukan pada saat hari-hari raya seperti hari natal dan saat ada acara di gereja.

\section{Kebutuhan Papan}

Kebutuhan akan papan atau tempat tinggal merupakan salah satu kebutuhan dasar yang dapat dikatakan sejalan dengan kebutuhan pangan, karena setiap orang selain butuh makan juga butuh tempat tinggal, untuk berteduh dari teriknya panas dan hujan, tempat untuk beristirahat melepaskan lelah setelah bekerja sepanjang hari, dan juga sebagai tempat berkumpulnya keluarga.

Berdasarkan hasil penelitian menunjukkan bahwa mayoritas rumah pemulung terbuat dari kayu/tripleks. Adapun status rumah semuanya milik sendiri namun untuk tanah adalah milik pemerintah (tanah negara).
Rumah-rumah gubuk yang ada di lokasi TPA Sumompo yang terbuat dari karton dan kardus adalah milik dari pendatang maupun milik dari pemulung yang tinggal agak jauh dari lokasi

Tabel 6. Jenis Bangunan Rumah Pemulung

\begin{tabular}{lcc}
\hline \multicolumn{1}{c}{ Jenis Rumah } & Jumlah & Persen \\
\hline Permanen & 1 & 6,6 \\
Semi & 4 & 6 \\
permanen & & \\
Kayu/tripleks & 1 & 26,67 \\
\hline Jumlah & 0 & 66,67 \\
\hline
\end{tabular}

Sumber : Data primer, 2016 (diolah)

Namun demikian mereka mempunyai rumah sendiri walaupun masih terbuat dari tripleks atau masih semi permanen.

Kondisi barang-barang yang ada dalam rumah juga mencerminkan bahwa pemulung merupakan masyarakat yang berpendapatan rendah. Untuk perabot seperti meja, kursi dan lemari ada pe-mulung yang mendapatkan secara mencicil bukan kredit dalam arti uang di setor di toko nanti sudah lunas baru barangnya diambil. Untuk alat-alat rumah tangga ada yang didapatkan di lokasi tempat sampah yang masih bisa digunakan dan ada pula yang dibeli dgn harga dan kualitas yang murah seperti piring yang terbuat dari plastik, dan sebagainya. Namun demikian . Rata-rata pemulung semua mempunyai televisi. Ada lima pemulung yang mempunyaai motor dan ada 2 pemulung yang mempunyai tabungan di bank.

\section{Keadaan Kesehatan}

Kesehatan pemulung umumnya baik karena hampir tidak pernah mengalami sakit yang parah. Kesehatan terganggu, hanya sakit yang ringan berupa flu dan batuk serta kelelahan dari bekerja sebagai pemulung yang diterjang hujan panas sehari-hari. Jika sakit responden yang tidak mempunyai kartu Jamkesnas maupun BPJS membeli obat di warung Sebaliknya responden yang mempunyai Jamkesnas 80 persen dari reponden memilih ke Puskesmas ataupun langsung ke dokter dan rumah sakit. 


\section{KESIMPULAN DAN SARAN}

\section{Kesimpulan}

1. Mekanisme bertahan hidup pemulung di lokasi TPA Sumompo berdasarkan kebutuhan pangan, dilakukan dengan pola makan dua kali sehari pagi dan sore, dengan mengkonsumsi ikan goreng dan kukus kadang tidak makan sayur.

2. Berdasarkan kebutuhan sandang, pemulung di TPA Sumompo rata-rata membeli pakaian satu kali dalam setahun, ada yang tidak dibeli melainkan atas pemberian orang atau didapatkan di lokasi TPA yang telah dibuang dan masih layak untuk dipakai.

3. Pemulung di TPA Sumompo rata-rata mempunyai rumah dengan status milik sendiri dan terbuat dari tripleks dengan ukuran dari $20 \mathrm{~m}^{2}$ sampai $42 \mathrm{~m}^{2}$. Peralatan dalam rumah sebagian dibeli sebagian didapatkan dari tempat sampah yang masih layak untuk dipakai. Untuk perabotan didapatkan secara mencicil di toko.

4. Jika ada kebutuhan yang sangat mendesak, pemulung di TPA Sumompo meminjam di koperasi, pinjam kepada tetangga maupun kepada bos tempat mereka menjual hasil memulung.

\section{Saran}

1. Untuk meningkatkan kebutuhan hidup dan dalam rangka untuk mempertahankan kehidupan harus ada usaha lain berupa usaha warung di rumah, berjualan bensin dan beternak babi sehingga kehidupan ekonomi keluarga menjadi lebih baik.

2. Pemerintah kiranya memberi perhatian dengan memberikan penyuluhan, pemeriksaan dan pengobatan gratis di lokasi TPA Sampah Sumompo.

\section{DAFTAR PUSTAKA}

Badriyah, H. 2015. Buku Pintar Akutansi Biaya untuk Orang Awam. Jakarta: Penerbit HB

BKPM. 2012. Komoditi Unggulan Daerah di Sulawesi Utara. http://regional investment.bkpm.go.id/newsipid/commo dityarea.php?ia=71\&ic=53 (diakses 19 Nov 2015)

Damanhuri, Enri. 2002. "Pengelolaan Persampahan yang bertumpu pada mengurangi dan men-Daur Ulang". Makalah, Forum Gelar Kota. ITB. Bandung.

Gunawan. 2012. Strategi Survival of Life Pemulung. Studi di Tempat Pembuangan Akhir Sampah Ganet Tanjungpinang. Naskah Publikasi Program Studi Sosiologi Fakultas Ilmu Sosial dan Politik Universitas Maritim Raja Ali Haji Tanjungpinang.

Hidayat, M. M., 2012. Profil Pemulung Sampah di Tempat Pembuangan Akhir (TPA) Kopi Luhur Kelurahan Argasunya Kecamatan Harjamukti Kota Cirebon, Universitas Pendidikan Indonesia, repository.upi.edu.

Ichsan. 1979. Kesehatan Lingkungan. PT. Rora Karya. Jakarta.

Manning, Chris dan Efendi Tadjuddin Noer. 1991. Urbanisasi, Pengangguran dan Sektor Informal di Kota. Yayasan Obor Indonesia. Jakarta.

Mintaroem, K., 1989. Penghasilan Pemulung di Kotamadya daerah tingkat II Surabaya. Lembaga Penelitian Universitas Airlangga. Surabaya.

Mudiyono, dkk. 2005. Dimensi-Dimensi Masyarakat dan Pemberdayaan Masyarakat. APMD Pres. Yogyakarta.

Notoatmodjo, Soekidjo. 2003. Pengembangan Sumber Daya Manusia. Rineka Cipta. Jakarta. 
Pusat Penelitian Sumberdaya Manusia dan Lingkungan Universitas Indonesia. Sistem Pengelolaan TPA Bantar Gebang, Bekasi (Jakarta: PPSML-UI, 2003).

Republika. 2013. Perlu Sinergitas Hadapi Masalah Pemulung. Jakarta.

Sadewo, Fx. S. 2007. Masalah-Masalah Kemiskinan di Surabaya. Unesa University Press. Surabaya.

Seow Ta Wee. 2012. Sumbangan Komuniti Pengutib Sampah dalam Pengurusan Sisa Pepejal di Malaysia. UTHM. Johor. Malaysia.

Sujarweni. V.T. 2015. Akutansi Biaya Teori dan Penerapannya. Yogyakarta. Penerbit Pustaka Baru Press

Sumarno, A., 2015. Strategi Pemenuhan Kebutuhan Pangan Masyarakat Miskin di Wilayah Slum Dukuh Kupang Barat. Jurnal on-line UNS, Surabaya.

Susanti, R., dan H. Asriwandari, 2012. Analisa Pertukaran Sosial Mengenai Pola Bekerja Pemulung di TPA Muara Fajar Kecamatan Rumbai Kota Pekan Baru. Laporan Penelitian.
Susanto, A. S., 1983. Pengantar Sosialogi dan Perubahan Sosial. Binacipta, Jakarta. Sutardji, 2009. Karakteristik Demografi dan Sosial Ekonomi Pemulung. Jurnal Geografi. Volume 6, No.2 Juli 2009.

Susianingsih. 2012. Kajian Geografis Kegiatan Pemulung Jalanan di Kecamatan Sawahan Kota Surabaya. Fakultas Ilmu Sosial Universitas Negeri Surabaya.

Teamphan, Z. 2013. Kehidupan Pemulung. PT. Grafindo. Jakarta. http://agussupu.wordpress.com/tag/peneli tian-pabrik-tepung-kelapa (diakses Oktober 2015).

Widdilestariningtyas, Anggadini, dan Firdaus. 2012. Akuntansi Biaya. Edisi Pertama. Yogyakarta: Graha Ilmu 